\title{
The effectiveness of cardiac rehabilitation in the sedentary cases with cardiovascular disease risk
}

\section{Kardiyovasküller riski olan sedanter yaşayan sağlıklı bireylerde kardiyak rehabilitasyon uygulamasının etkinliği}

Emrullah Hayta

Department of Physical Medicine and Rehabilitation, Cumhuriyet University Faculty of Medicine, 58140 Sivas, Turkey
Corresponding author: Emrullah Hayta, Department of Physical Medicine and Rehabilitation, Cumhuriyet University
Faculty of Medicine, 58140 Sivas, Turkey
E-mail: dremay@ gmail.com
Received/Accepted: June 30, 2016 / August 17, 2016
Conflict of interest: There is not a conflict of interest.

\section{SUMMARY}

Objective: The aim of the present study is to apply cardiac rehabilitation (CR) to the sedentary cases with cardiovascular disease (CVD) risk, and to investigate the effect of CR on the various blood parameters and aerobic capacity of the cases.

Method: The study included 106 individuals with sedentary life. Age, smoking history, presence of anxiety, CVD and DM history, pulmonary disease history, alcohol use, dietary habits, lipid profile, ECHO test of the patients were determined before the cardiac rehabilitation application. Furthermore, body mass index (BMI) values, weight, waist-hip-thigh circumference, lipid profile, Metabolic Equivalent of Task (MET), and VO2 Max of all patients were measured. The patients who had a sedentary lifestyle were then put to respiratory function test, submaximal exercise test, and ECG-CB monitoring and treadmill-ergometric stress tests. The patients who responded well to the tests were included in an aerobic program for 12 weeks (30-50 min of aerobic exercise, 5 days/3 weeks) based on the exercise tolerance test according to their clinical condition. Besides, the parametric measurements, which had been conducted prior to the aerobic program, and the results of the pre and post tests were evaluated and compared at the end of the 12th week.

Results: There were meaningful improvements in body weights, BMI, waist and hip and EKO measurements of the individuals included in the study $(\mathrm{p}<0.005)$. The difference between triglyceride, HDL, LDL, MET, AT, VO2 max and body fat rate of the study participants before and after CR were found statistically significant $(\mathrm{p}<0.005)$.

Conclusions: In the present study, CR applied to individuals having sedentary lifestyle has positive impacts on BMI decrease, body fat rate and lipids. Besides, CR achieves a significant increase in aerobic capacity in individuals having sedentary lifestyle

Keywords: Sedentary life, Cardiac rehabilitation, Aerobic capacity 


\section{ÖZET}

Amaç: Sedanter yaşayan ve Kardiyovasküler riski olan (KVH) bireylere Kardiyak Rehabilitasyon (KR) uygulaması yapmak, KR uygulamasının hastanın çeșitli kan parametreleri ve aerobik kapasite üzerine olan etkisini araştırmaktır.

Yöntem: Bu çalışmaya 106 sedanter yaşayan sağlıklı bireyler alındı. Sedanter yaşayan sağlıklı bireyler kardiyak rehabilitasyon uygulaması öncesi yaş, sigara öyküsü, anksiyetinin varlı̆̆ı, KVH ve DM öyküsü, pulmoner rahatsızlık öyküsü, alkol kullanımı, diyet alışkanlığı, lipid profili, EKO ölçümleri yapıldı. Ayrıca tüm hastaların vücut kütle oranı (BMI) değeri, kilosu, bel-kalça-uyluk çevresi ölçümü, lipit profili, metabolik eşdeğer (MET) ve VO Max ölçümü yapıldı. Sedanter bireylere daha sonra solunum fonksiyon testi, submaksimal egzersiz testi, EKG-KB monitörizasyonu ile koşu bandi protokolleri uygulandı. Bu aşamalarda testlere iyi yanıt veren hastalar klinik durumlarına göre egzersiz tolarans testi refarans alınarak koşu bandında 12 haftalık (30-50 dakika/5gün) aerobik egzersiz programına alındı. Ayrıca hastaların 12.haftanın sonunda ilk yapılan parametrik ölçümleri tekrar yapılarak değerlendirildi.

Bulgular: Çalışmaya alınan bireylerin KR uygulama sonrası vücut ağırlığı (VA), BMI, bel-kalçauyluk çevresi ve EKO ölçümlerinde anlamlı düzelmeler vardı $(\mathrm{p}<0.005)$. Yine trigiliserit, LDL, HDL, kolesterol, MET, AT ve VO2 max değerleri karşılaştırıldığında farklılık istatistiksel açıdan önemli bulundu $(\mathrm{p}<0.005)$.

Sonuç: KR uygulamasının sedanter yaşayan kişilerde, BMI azalması, vücut yağ oranı, lipitler üzerine olumlu gelişmeler yapmaktadır. Ayrıca KR uygulaması sedanter yaşayan bireylerde aerobik kapasite üzerine anlamlı artma yapmaktadır

Anahtar sözcükler: Sedantar Yaşam, Kardiyak Rehabilitasyon, Aerobik kapasite

\section{INTRODUCTION}

Lack of movement in modern life is described as sedentary lifestyle, and indicated as one of the major causes of several fatal diseases. With decreased physical activity, the calories consumed also decreases, leading to risk factors such as insulin resistance, blood lipid disorders and hypertension as well as obesity, and reduced cardiovascular functional capacity ${ }^{1-3}$. According to World Health Organization's report in 2002, sedentary lifestyle causes $10-16 \%$ of the breast cancer, colon cancer and diabetes mellitus, and $22 \%$ of cardiac diseases across the world. Furthermore, the incidence of several diseases such as obesity, weakness in muscle strength and postural deformity are found to be higher in sedentary individuals ${ }^{4-6}$.

By increasing aerobic capacity of sedentary individuals, it is possible to minimize or prevent these diseases frequently accompanying a sedentary lifestyle ${ }^{7,8}$. There are various methods used to increase aerobic capacity, one of which is cardiac rehabilitation (CR) practices. CR is a multidisciplinary approach including all studies conducted for the purpose of providing optimal physical, mental and social conditions that are required for recovering functional capacity. In daily practice, CR might be considered as a practice where aerobic exercises for increasing patient's physical capacity are done $e^{9-12}$.

The meta-analyses which assessed CR efficiency reported that it induced reduction of cardiac mortalities and other mortalities associated coronary heart disease, and decrease of triglyceride levels and systolic blood pressure, and lower smoking rates ${ }^{13-15}$. Similarly, another clinical study demonstrated that $\mathrm{CR}$ brought about significant gains in medical, social and economic spheres by increasing muscle strength and endurance, and yielding positive effects on physical function and life quality ${ }^{16-18}$.

There are a large number of studies investigating the efficiency of aerobic exercise in individuals having a sedentary lifestyle. Yet, only few studies investigated the effects of CR practice on body fat distribution and aerobic capacity of the individuals having a sedentary lifestyle. The objective of the present study is to apply CR practice to the subjects having a sedentary lifestyle with cardiovascular disease (CVD) risk, and to investigate the effect of $\mathrm{CR}$ practice on 
body fat distribution and aerobic capacity.

\section{MATERIAL AND METHODS}

\section{Study Group}

The study was composed of 106 individuals with sedentary lifestyle with an age range of 30-35 having coronary artery disease risk admitted in and deemed suitable for cardiac rehabilitation in Cardiology Clinic of Physical Therapy and Rehabilitation Cumhuriyet University between July 2013 and January 2015. The patients with unstable angina, uncontrollable arrhythmias, symptomatic congestive heart failure, aorta stenosis, sinus rhythm and beta blocker medication use were excluded. Moreover, patients with recent MI, serious infections, endocarditis, pericarditis, myocarditis, and those having balance issues while walking on treadmill and those with uncontrollable tachycardia history during the exercise were also excluded.

\section{Study Design}

Age, smoking history, presence of anxiety, CVD and DM history, pulmonary disease history, alcohol use, dietary habits, lipid profile, ECHO test of the patients were determined before the cardiac rehabilitation application. Furthermore, body mass index (BMI) values, weight, waist-hip-thigh circumference, lipid profile, Metabolic Equivalent of Task (MET), and VO2 Max of all patients were measured. The patients who lived a sedentary lifestyle were then put to respiratory function test, submaximal exercise test, ECG-CB monitoring and treadmill-ergometric tests. The patients who responded well to the tests were included in an aerobic program for 12 weeks (3 days a week) based on the exercise tolerance test according to their clinical condition. Besides, the parametric measurements which had been conducted initially were repeated and evaluated at the end of the $12^{\text {th }}$ week.

\section{Cardiopulmonary Tests}

The calculation was made using SFT Care Fusion ergospirometry device. The calibration of the device was repeated before each test. 'Breath by breath' analysis system was used in order to measure VO2 Max. In this system, VO2, $\mathrm{VCO} 2$ and the air volume expired per minute (VE) is calculated by analyzing the gas in the ventilation air. AT was defined as the $\mathrm{VO} 2$ value when Respiratory Quotient (RQ), which is the rate obtained by dividing $\mathrm{VCO} 2$ by $\mathrm{VO} 2$, equaled to 1 . All values were calculated by averaging them at 20 -second intervals. Moreover, Metabolic Equivalent of Task (MET) value, AT time and exercise duration were recorded.

\section{Measurement of Height and Bodyweight and Body Mass Index (BMI)}

The ages of the participants were calculated by subtracting their birth date from the current year, and their height were measured in centimeters using a Rodi Super Quality meter, and their body weights (BW) were measured in kilograms through a Premier electronic scale, and the values were recorded. Body Mass Index (BMI) was calculated according to Pollock formula (BMI=BW $(\mathrm{kg}) /$ Height $\left.\left(\mathrm{m}^{2}\right)\right)$. The heights of the participants were measured as they stood barefooted ${ }^{19}$.

\section{Body fat rate measurement}

The patients were administered bioelectric impedance analysis on empty stomach and empty bladder on the morning of anthropometric measurements following at least 8 hours of night rest. Tanita Body Composition Analyzer TBF 300 was used for the procedure. The patients were advised to drink 7-8 glasses of water but no excessive coffee and tea or cigarette smoking during the previous day. Any metals and ornaments and large metal clothing items (such as belt) were removed during the tests and exercise. The individuals to be measured were requested to step on aluminum base of Tanita device being clothed but barefooted in a vertical position. Afterwards, the device was switched on, and required information was entered and measurement was conducted. Hip circumference was measured on the line level passing through most protruding 
point of gluteus maximus muscle and pubis $^{20}$.

\section{ECHO Measurement}

ECHO analyses of all patients participating in the study were conducted by the same cardiologist. The analyses were conducted in left decubitus position using Transthoracic Echocardiography Vivid 7 Dimension (2008).

\section{Blood Sample}

Blood samples were collected in the morning following at least 12 hours of night fasting. TK, triglyceride, HDL, and LDL were identified as parameters. TK, HDL cholesterol and triglyceride levels were studied through colorimetric method in Olympus AU 5223 analyzer. Insulin was analyzed daily through electrochemiluminescence immunoassay (ECLIA). Chemiluminescence enzyme immunometric method was used in determining the thyroid function tests.

\section{Implementation of Exercise Program}

Individual exercise prescription was prepared taking into account the data obtained as a result of Exercise Tolerance Test. In the exercise program with 3 days exercise a week in 12-week period involving fast walking and low-intensity running, the intensity (force) was calculated through Karvonen formula taking into account the maximal heart rate (MHR) reached during exercise tolerance test (ETT): Target Heart Rate $=$ (MHR - Resting Heart Rate) x (50-60\%) + Resting Heart Rate. Warm up (5 minutes), and main part (30-50 minutes) and cooling (5-10 minutes) stages were followed with regard to duration. While the total duration was 45 minutes initially, it was increased by 10 minute at the beginning of weeks 5 and 9 . In the warm up and cooling parts of the exercise, isometric, isotonic, flexibility (mobility) and stretching exercises were done targeting large muscle groups including lower-upper extremities and waist region. Exercises were implemented every other day being 3 predefined days a week with regard to frequency. Exercise sessions were conducted on Activa AC 6350 treadmill within appropriate pulse interval ${ }^{21}$.

\section{Statistical analysis}

All data were analyzed using IBM SPSS ver. 21 (IBM Co., Armonk, NY, USA). Paired t-test was used for comparing the parametric values before and after the therapy. In the assessment of normality, Kolmogorov-Smirnov test was used. Wilcoxon test was conducted in evaluating the non-parametric data. The data obtained from the groups were determined as arithmetic mean \pm standard deviation (SD), number of individuals (n) and percentage (\%). A p value of less than 0.05 was accepted as significant.

\section{RESULTS}

Minimum and maximum ages of 106 patients included in the study were 30 and 55 , with a value of $43.67 \pm 10.59$ years. 31 of them $(29.2 \%)$ were males while 75 $(70.8 \%)$ were females.

36 of the individuals (34\%) had anxiety, while 70 individuals $(66 \%)$ were free from anxiety. 61 of them $(57.5 \%)$ were working individuals, whereas 45 (42.5\%) did not work.

12 of the individuals (11.3\%) had regular diet, while $94(88.7 \%)$ had irregular eating habits. While $46(43.4 \%)$ of the individuals followed a diet, $60(56.6 \%)$ did not. 31 of them (29.2\%) had CVD history, but 75 (70.8\%) did not. 8 of them (7.5\%) had moderate pulmonary complaints, while 98 (92.5\%) had a history of moderate pulmonary disease. 16 of the individuals (15.1\%) had DM history, $90(84.9 \%)$ did not have DM diagnosis. While 5 individuals $(4.7 \%)$ used alcohol, 101 (95.3\%) did not. 16 of the individuals $(15.1 \%)$ were smokers, while 90 (84.9\%) were non-smokers.

Comparing BW, BMI, waist-hip-thigh circumference and ECHO measurements of the participating individuals before and after CR, the difference was found statistically significant $(\mathrm{p}<0.005)$ (Table $1)$. 


\section{CMJ Original Research September 2016, Volume: 38, Number: 3}

Cumhuriyet Medical Journal

202-210

Table 1. BW, BMI, waist-hip-thigh circumference and ECHO measurements of the participating individuals before and after CR

\begin{tabular}{|l|c|c|c|}
\hline & Before CR & After CR & Result \\
\hline BW $(\mathrm{kg})$ & $89.6 \pm 18.5$ & $82 \pm 16.6$ & $\mathrm{t}=14.76$ \\
& & & $\mathrm{p}=0.001$ \\
\hline BMI $\left(\mathrm{kg} / \mathrm{m}^{2}\right)$ & $33.1 \pm 6.8$ & $30 \pm 6.5$ & $\mathrm{t}=13.63$ \\
& & & $\mathrm{p}=0.001$ \\
\hline $\begin{array}{l}\text { Waist circumference } \\
(\mathrm{cm})\end{array}$ & $103 \pm 17.6$ & $94.8 \pm 15.5$ & $\mathrm{t}=19.24$ \\
\hline $\begin{array}{l}\text { Hip circumference } \\
(\mathrm{cm})\end{array}$ & $114.8 \pm 13$ & $107.7 \pm 11.5$ & $\mathrm{p}=0.001$ \\
\hline $\begin{array}{l}\text { Thigh circumference } \\
(\mathrm{cm})\end{array}$ & $57.5 \pm 7.2$ & & $\mathrm{t}=16.99$ \\
& & $54 \pm 7$ & $\mathrm{p}=0.001$ \\
\hline ECHO EF\% & $58.6 \pm$ & $60.5 \pm 4.51$ & $\mathrm{t}=12.03$ \\
& & & $\mathrm{p}=0.001$ \\
\hline
\end{tabular}

The difference between triglyceride, HDL, LDL, MET, AT, VO2 max and body fat rate of the study participants before and after CR were found statistically significant $(\mathrm{p}<0.005)$ (Table 2). 
Table 2. Triglyceride, LDL, HDL, cholesterol measurements, Metabolic Equivalent (MET), Anaerobic Time (AT), VO2 max and body fat rate values of sedentary individuals before and after $\mathrm{CR}$.

\begin{tabular}{|l|c|c|c|}
\hline & Before CR & After CR & Result \\
\hline Triglyceride (mg/dL) & $169.5 \pm 95.3$ & $135.1 \pm 60.5$ & $\begin{array}{c}\mathrm{t}=5.92 \\
\mathrm{p}=0.001\end{array}$ \\
\hline LDL (mg/dL) & $120.9 \pm 34.7$ & $104 \pm 24.6$ & $\mathrm{t}=8.1$ \\
& & & $\mathrm{p}=0.001$ \\
\hline HDL (mg/dL) & $43.7 \pm 10.8$ & $52.4 \pm 12.4$ & $\mathrm{t}=8.98$ \\
& & & $\mathrm{p}=0.001$ \\
\hline Cholesterol (mg/dL) & $88.1 \pm 36.9$ & $164.8 \pm 31$ & $\mathrm{t}=8.57$ \\
& & & $\mathrm{p}=0.001$ \\
\hline MET & $5.9 \pm 1.5$ & $7.4 \pm 1.5$ & $\mathrm{t}=18.53$ \\
& & & $\mathrm{p}=0.001$ \\
\hline Anaerobic Time (min) & $19.1 \pm 4.3$ & $25.9 \pm 5.5$ & $\mathrm{t}=14.72$ \\
& & & $\mathrm{p}=0.001$ \\
\hline VO ${ }_{2}$ max $(\mathrm{ml} / \mathrm{kg} / \mathrm{min})$ & $22.5 \pm 5.5$ & $25.9 \pm 5.1$ & $\mathrm{t}=11.26$ \\
& & & $\mathrm{p}=0.001$ \\
\hline Body fat rate (\%) & $37.9 \pm 7.7$ & $33.0 \pm 6.4$ & $\mathrm{t}=13.95$ \\
& & & $\mathrm{p}=0.001$ \\
\hline
\end{tabular}

\section{DISCUSSION}

The difference in body weight, BMI, body fat rate, waist-hip-thigh circumference measurements and blood lipid levels of the sedentary individuals included in this study before and after CR was found significant. Furthermore, $\mathrm{VO} 2$ max and MET values, which are markers of aerobic capacity, increased. Our study has shown that CR induces an increase in aerobic capacity, and a decrease in body fat distribution and an improvement in lipid profile. These findings are in line with the related literature.

The impact of aerobic exercise on body weight in individuals having a sedentary lifestyle was previously demonstrated by various clinical studies ${ }^{22-24}$. In a study conducted by Asikainen et al. ${ }^{25}$, some of the women going through menopause were prescribed with walking exercise at $65 \%$ intensity of their maximal aerobic power 5 days a week for a 15 -week period, while some others followed the same exercise twice a day. At the end of the study, the group doing the exercise 5 days a week achieved $-1.2 \mathrm{~kg}$ of weight loss, while the other group achieved - 1.1 $\mathrm{kg}$ of weight loss. In our study, exercise was done 3 days a week at $80 \%$ intensity of the aerobic power on a treadmill, and we found a weight loss of 7,6 kg in the sedentary individuals. We attribute the weight loss to the exercise at $80 \%$ intensity of the aerobic power and our recommendation for a low caloric diet to the patients.

The fact that aerobic activities reduce the risk of coronary cardiac diseases has long been known ${ }^{26,27}$. Lakusic et al. ${ }^{28}$ found in their study that following a 3-week cardiac rehabilitation program, TK, triglyceride and LDL-cholesterol levels decreased significantly, while the HDLcholesterol levels increased significantly. We found in this study that triglyceride, LDL, HDL and TK levels decreased significantly following the exercise. The decrease in blood lipids at the end of aerobic exercise is associated with reasons such as the fact that more than 
$50 \%$ of the energy during exercise is derived from fats, and a large amount of energy required by body during long exercises is derived from free fat acid molecules ${ }^{29,30}$.

Doing aerobic exercise induces increase in functional capacity. 1 MET increase in functional capacity reduces the risk of any cardiovascular event occurrence by $25 \%$ in both males and females ${ }^{31}$. Barbara et al. ${ }^{32}$ found an increase of approximately 2 MET in the patients in a clinical study involving 24-week CR applied to 79 ischemic heart patients, and described the increase as significant. In our study, we found an increase of 1,5 MET, which was significant compared to the case norms prior to the exercise. Large number of studies report that moderate intensity aerobic exercises done regularly increase VO2 max. It is argued that aerobic capacity can be increased through at least 6-week trainings with 3-5 days a week for a period of 15-60 minutes ${ }^{33}$. Weston et al. ${ }^{34}$ found in a meta-analysis including 10 clinical studies and a total number of 273 CHD patients that aerobic exercise induces an average $9,1 \%$ of increase in VO2 max

In conclusion, $\mathrm{CR}$ applied to individuals having sedentary lifestyle has positive impacts on BMI decrease, body fat rate and lipids. Besides, CR achieves a significant increase in aerobic capacity in individuals having sedentary lifestyle. Nevertheless, future randomized controlled studies are necessary in order to demonstrate the efficiency of CR practices in individuals having sedentary lifestyle.

\section{REFERENCES}

1. Tremblay MS, Colley RC, Saunders TJ, Healy GN, Owen N. Physiological and health implications of a sedentary lifestyle. Appl Physiol Nutr Metab 2010; 35: 725-40.

2. Baynard $\mathrm{T}$, Carhart RL Jr, Weinstock RS, Ploutz-Snyder LL, Kanaley JA. Short-term exercise training improves aerobic capacity with no change in arterial function in obesity. Eur J Appl Physiol 2009; 107: 299-308.

3. Guo, SS, Zeller, C, Chumlea, WC, Aging, Body Composition and Lifestyle: The Fels Longitudinal Study. Am J Clin Nutr 1999; 70: 405-11.

4. Athyros VG, Ganotakis ES, Bathianaki M, et al. MetS-Greece Collaborative Group. The prevalence of the metabolic syndrome in Greece: The MetSGreece Multicentre Study. Diabetes Obes Metab 2005; 7: 397-405.

5. Pitsavos C, Panagiotakos DB, Lentzas Y, Stefanadis C. Epidemiology of leisure-time physical activ ity in sociodemographic, lifestyle and psychological characteristics of men and women in Greece: the Attica Study. BMC Public Health 2005; 5: 37-45.

6. Salmon J, Bauman A, Crawford D, et al. The association between television viewing and overweight among Australian adults participating in varying levels of leisure-time physical activity. Int $\mathbf{J}$ Obesity Related Metabolic Disorders 2000; 24: 600-6.

7. Craig CL, Russell SJ, Cameron C, et al. Twenty-year trends in physical activity among Canadian adults. Can J Public Health 2004; 95: 59-63.

8. Janssen I, Katzmarzyk PT, Boyce $\mathrm{WF}$, et al. Comparison of overweight and obesity prevalence in school-aged youth from 34 countries and their relationships with physical activity and dietary patterns. Obesity Reviews 2005; 6: 123-32.

9. Grace SL, Grewal K, Arthur HM, Abramson BL, Stewart DE. A prospective, controlled multisite study of psychosocial and behavioral change following women's cardiac rehabilitation participation.J Womens Health (Larchmt) 2008; 17: 241-8.

10. Giannuzzi P, Mezzani A, Saner H, Björnstad H, Fioretti P, Mendes M, et al. Physical activity for primary 
and secondary prevention. Eur $\mathbf{J}$ Cardiovasc Prev Rehabil 2003; 10 : 319-27.

11. Mendes M. Is There a Role for Cardiac Rehabilitation After Coronary Artery Bypass Grafting? There is No Role for Cardiac Rehabilitation After Coronary Artery Bypass Grafting.Circulation 2016; 133: 2538-43.

12. Pourafkari L, Ghaffari S, Shahamfar J, Tokhmechian L, Nader ND. The psychological effects of cardiac rehabilitation after coronary revascularization.Turk Kardiyol Dern Ars 2016; 44: 228-36.

13. Anderson L, Thompson DR, Oldridge N, Zwisler AD, Rees K, Martin N, Taylor RS. Exercisebased cardiac rehabilitation for coronary heart disease.Cochrane Database Syst Rev. 2016; 5: CD001800.

14. Sandesara PB, Lambert CT, Gordon NF, Fletcher GF, Franklin BA, Wenger NK, Sperling L. Cardiac rehabilitation and risk reduction: time to "rebrand and reinvigorate". J Am Coll Cardiol. 2015; 65: 389-95.

15. Gaalema DE, Cutler AY, Higgins ST, Ades PA. Smoking and cardiac rehabilitation participation: Associations with referral, attendance and adherence. Prev Med 2015; 80: 67-74.

16. Houle J, Doyon O, Vadeboncoeur N, Turbide G, Diaz A, Poirier P. Effectiveness of a pedometer-based program using a socio-cognitive intervention on physical activity and quality of life in a setting of cardiac rehabilitation. Can J Cardiol 2012; 28: 27-32.

17. Lalonde F, Poirier P, Arvisais D, Curnier D. Exercise-induced ischemic preconditioning and the potential application to cardiac rehabilitation: a systematic review.J Cardiopulm Rehabil Prev 2015; 35: 93-102.

18. Oldridge NB, Pakosh MT, Thomas RJ. Cardiac rehabilitation in lowand middle-income countries: a review on cost and cost-
effectiveness.Int Health 2016; 8: 77 82.

19. Romero-Corral A, Somers VK, Sierra-Johnson J, Thomas RJ, Collazo-Clavell ML, Korinek et al. Accuracy of body mass index in diagnosing obesity in the adult general population. Int $\mathrm{J}$ Obes (Lond) 2008; 32: 959-66.

20. Lohman TG. Skinfolds and body density and their relation to body fatness: A review.Hum Biol 1981; 53: 181-225.

21. Mann S, Beedie C, Jimenez A. Differential effects of aerobic exercise, resistance training and combined exercise modalities on cholesterol and the lipid profile: review, synthesis and recommendations. Sports Med 2014; 44: 211-21.

22. Thorogood A, Mottillo S, Shimony A, Filion KB, Joseph L, Genest J,et al. Isolated aerobic exercise and weight loss: a systematic review and meta-analysis of randomized controlled trials. Am J Med 2011; 124: 747-55.

23. Moderate exercise training provides modest protection against adipose tissue inflammatory gene expression in response to high-fat feeding.Linden MA, Pincu Y, Martin SA, Woods JA, Baynard T. Physiol Rep 2014: 16; 2.

24. Baynard T, Carhart RL Jr, Weinstock RS, Ploutz-Snyder LL, Kanaley JA. Short-term exercise training improves aerobic capacity with no change in arterial function in obesity. Eur J Appl Physiol 2009; 107: 299-308.

25. Asikainen TM, Miilumpalo S, Oja P, Rinne M, Pasanen M, Uusi-Rasi K, Vuori I. Randomised controlled walking trials in post menopausal women: The minimum dose to improve aerobic fitness? Br J Sports Med 2002; 36: 189-194.

26. Cheng AY, Leiter LA. Implications of recent clinical trials for the National Cholesterol Education Program Adult Treatment Panel III 
guidelines. Curr Opin Cardiol 2006; 21: 400-4.

27. Pattyn N, Cornelissen VA, Eshghi SR, Vanhees L. The effect of exercise on the cardiovascular risk factors constituting the metabolic syndrome: a meta-analysis of controlled trials. Sports Med. 2013; 43: 121-33.

28. Lakusic N, Mahovic D, Ramqaj T, Cerovec D, Grbavac Z, Babic T. The Effect of 3-Weeks Stationary Cardiac Rehabilitation on Plasma Lipids Level in 444 Patients With Coronary Heart Disease, CollAntropol 2004: 28; 623-9.

29. Sousa N, Mendes R, Abrantes C, Sampaio J, Oliveira J. A randomized study on lipids response to different exercise programs in overweight older men. Int J Sports Med 2014; 35: 1106-11.

30. Guzel NA, Pinar L, Colakoglu F, Karacan S, Ozer C. "Long-term callisthenic exercise-related changes in blood lipids, homocysteine, nitric oxide levels and body composition in middle-aged healthy sedentary women". Chin J Physiol 2012: 30; 55: 202-9.

31. Merz CNB, Alberts MJ, Balady GJ, Ballantyne CM, Berra K, Black HR, Blumenthal RS, Davidson MH, Fazio SB, Ferdinand KC, Fine LJ, Fonseca V, Franklin BA, McBride PE, Mensah GA, Merli GJ, O’Gara PT, Thompson PD, Underberg JA. ACCF/AHA/ACP 2009 Competence and Training Statement: A Curriculum on Prevention of Cardiovascular Disease. Circulation 2009; 120: 100-26.

32. Sandor B, Nagy A, Toth A, Rabai M, Mezey B, Csatho A, Czuriga I, Toth K, Szabados E. Effects of moderate aerobic exercise training on hemorheological and laboratory parameters in ischemic heart disease patients. PLoS One. 2014: 27; 9: 110751.

33. Fitzgerald MD, Tanaka H, Tran ZV, Seals DR. Age-related declines in maximal aerobic capacity in regularly exercising vs. sedentary women: a meta-analysis. J Appl Physiol (1985). 1997 Jul; 83: 160-5.

34. Weston KS, Wisløff U, Coombes JS. High-intensity interval training in patients with lifestyle-induced cardiometabolic disease: a systematic review and metaanalysis. Br J Sports Med 2014: 48; 1227-34. 